\title{
Analysis of Use of Mobile Media: Reasons of Use and Degree of Satisfaction Among Student Users of Mobile Media at Moscow Universities
}

\author{
Dogancay Irina, $\mathrm{PhD}$ 's \\ Institute of Communication, East China Normal University, Shanghai, China \\ E-mail: irinadgncy@gmail.com
}

Received: May 14, 2019 Accepted: May 31, 2019 Online published: June 4, 2019

doi:10.5296/ijhrs.v9i2.14889 URL: https://doi.org/10.5296/ijhrs.v9i2.14889

\begin{abstract}
What is the role of mobile media in public life today? What is its origin? How did it evolve, and how efficient is it in our lives? These are all surging topics research literature in today's virtually interconnected world. There is no shortage of researchers in the modern world now focusing solely on how mobile media's role in the world has taken shape, and how powerful it is, what impact it has on humanity, and so on.

In this study, before considering reasons of use and the degree of satisfaction students at Moscow universities find in their usage of mobile media in particular, then pans out to discuss how this reflects on more general trends in the usage of mobile media in today's world, I consider the general picture of the process of using mobile media and examine more closely one particular part of the complex new process of mass communication - analysis the audience of mobile media and the general picture of the process of using mobile media at Moscow universities.
\end{abstract}

Keywords: mobile media, university students, Moscow, uses and gratifications theory

\section{Introduction}

Firstly, countless mobile media content comes into the public view every minute of the day. The importance and influence of this content in the modern world can't be underestimated. Mobile media has become a powerful instrument of influence, capable of simultaneously impacting large numbers of people, at a rate unprecedented in all of human history. Among the entire audience of mobile media, this study aims to highlight the student demographic of the mobile media audience. Students are a special, very interesting, mobile and specific community of people, united by their enrollment in institutions of higher education. It is 
students who hold the majority of the intellectual and managerial potential in their generation, and who are also the potential elite of any society as a whole.

This study examined the student mobile media audience, through the lens of students at various Moscow universities. It is certain that mobile phones greatly facilitate day-to-day life, every minute performing a variety of diverse functions. However, the perceived convenience of having constant access to these sets of various functions makes us directly dependent on mobile phones. In this regard, considering the overall picture of the use of mobile media by students of Moscow universities, this study dwells in more detail on how many hours per day respondents spend on the use of mobile phones, considers the respondents' level of dependence on them.

Secondly, since 1940s, scientists started to actively explore the reasons for choosing certain radio programs and periodicals. In the 1940s a more pronounced interest in studying the reasons for using the mass media from the psychological side was noticed as well. Paul Lazarsfeld, Bernard Berelson and others concluded that "the audience is attracted to a variety of opportunities that can provide the media - from the acquisition of knowledge to emotional discharge" [Katz, 1973].

Already by the 1970s, researchers found that the needs of the audience are determined by social and psychological factors. It was also revealed that the use of mass media improves not only the understanding of oneself, but also the understanding of audience as a whole. Moreover, the media can be used to raise social status and strengthen social relations. Denis McQuail, Jay Blumler and others in 1972 offered their own typology of reasons for using the media. They identified such motives as "entertainment, the need for communication, enhancing personal identity and the need to obtain information about recent events" [McQuail, Blumer \& Brown, 1972].

From the mid-1970s, the application of similar research methods to the study of the reasons for using the media can be eliminated. Ruslan Greenberg and A. Rubin found that the reasons for using the media change with age. Today, most scientists working on the theory of use and satisfaction, distinguish the following motives for using mass media: training, habit, maintaining a company, getting excited, relaxing, avoiding reality, filling free time. Soon, we take a closer look at the reasons for the use of mobile media by students of Moscow universities.

Thirdly, uses and gratifications theory (UGT, uses and gratifications theory) is the theory that surveys the audience's part in decision making and definition of goals in the process of its consuming of mass media products. Significant contribution in the research of the audience's preferential usage of different mass media was made by such scientists as Ellahu Kutz, Hadasaah Haas, Michel Gurevich and others. The main purpose of the uses and gratifications theory - is 'to explain social and psychological needs that define the factors of preference of the means of communication and involve the audience in certain channels of communication' [LaRose, Mastro \& Eastin, 2001]. Over the past few decades, the Uses and gratifications theory evolved in accompaniment with the development of technology and the advent of digital media. Behavioral aspects of users of the digital environment are being studied today. 


\section{Macrothink}

International Journal of Human Resource Studies

ISSN 2162-3058

2019, Vol. 9, No. 2

Followers of the use and gratification theory are convinced that "the audience uses the media for a specific purpose, and the choice of a particular media depends on the degree of achievement of the tasks and the ability to implement them through the selected media" [Pavlou, Liang \& Xue, 2006].

The motivations for using mobile media define the ways of behavior of different users of mobile media, and the degree of satisfaction reached after its use encourages its further use and consequent usage habits. The survey is dedicated to learning the degrees to which students are satisfied using mobile media in five dimensions; very satisfied, satisfied, partially satisfied, not satisfied, absolutely not satisfied.

\section{Literature Review}

Despite extensive research and analysis of a wide range of sources, the number of research articles written on mobile media in particular, is still quite low. Keywords include the studies done by Chinese scientists Zhu Hai Song [Zhu, 2008], Yan San Jiu [Yan, 2011], Kuang Wen Bo [Kuang, 2012] etc., a compilation edited by Gerard Gogg in and Larissa Hjorth [Goggin \& Hjorth, 2017], and an electronic edition edited by Svetlana Balmaeva and Maria Lukina [Balmaeva \& Lukina, 2016]. Never the less, the theme of reasons of use and the satisfaction degree of the use of mobile media has recently begun to be increasingly covered in academic journals by scholars such as Lu Jing [Lu, 2015], Ma Ye [Ma, 2012] as well as many others.

\section{Research Methodology and Procedure}

This study employed an analytical research methodology; data was collected with help of a survey questionnaire. Critical analysis was carried out on the collected data.

\subsection{Population}

The target population for the study was bachelor's and master's students from universities in Moscow, Russia. Students were recruited from three levels of Moscow universities, high-level (Moscow State University), moderately high-level (Moscow State Pedagogical University) and mid-level (State University of Management).

\subsection{Sample}

The student sample for this study was composed of 320 participants and the sample was chosen using the Purposive Sampling Technique.

The data type is Nominal Scales (labels), including dichotomous and Ordinal Scales.

\subsection{Variable}

Mobile media as the Independent Variable.

Satisfaction degree of the use of mobile media as the Dependent Variable.

\subsection{The Objective of the Study}

To gain a general picture of the satisfaction degree of the use of mobile media among the students of Moscow universities 


\section{Findings and Discussion}

\subsection{The General Picture of the Process of Using Mobile Media at Moscow Universities}

\subsubsection{Analysis of the Audience of Mobile Media at Moscow Universities}

First, to summarize the total number of respondents in this survey, there was a total of 320 people from Moscow State University, MPGU, and GUU. Regarding the ratio of male respondents to female respondents, the respondents were mostly female students $(70.63 \%)$. The ages of the respondents mostly ranged from 18 to 22 years old $(80.21 \%)$.

Other demographic majorities among the respondents were undergraduate students $(89.69 \%)$, students of the humanities (67.5\%), students who were originally from cities $(92.50 \%)$, single students (not in a committed romantic relationship (56.25\%). And almost half of the respondents reported themselves to be Christians (49.38\%).

Secondly, considering the general situation of the use of mobile media by students of Moscow universities, an overall picture emerges: almost all students (96.25\%) of Moscow universities use smartphones, mainly choosing the iPhone, Samsung Galaxy, Xiaomi; the respondents were almost evenly split between prepaid plan subscribers and unlimited internet subscribers ( $44.19 \%$ and $55.81 \%$ ); the main location for using mobile internet was the home (78\%); also, $3.13 \%$ of the total number of respondents refuse to use mobile internet on principle.

Mobile newspapers, television and similar sources are used by slightly more than half of respondents $(54.84 \%)$, who largely prefer mobile video (48\%), mobile newspapers $(26 \%)$, and mobile cinema (24\%).

\subsubsection{Analysis of the Time Spent Per Day Using a Mobile Phone at Moscow Universities}

As students constitute the core potential of any society, to whom it is necessary to show special attention and care, it is advisable to raise awareness to trends in extreme tendencies among university students and their use of mobile media - case in point, 56.94\% of Moscow University students use their mobile phones for five or more hours per day.

According to the data on the table below, $6.88 \%$ of Moscow students use a mobile phone for about an hour a day, $37.19 \%$ use a mobile phone for 1 hour to 5 hours a day, $35 \%$ use their phones from 5 to 10 hours a day, and $20.94 \%$ use their phones for 10 hours or more per day.

Table 1. "Time interval per day" when using a mobile phone

\begin{tabular}{l|l|l}
\hline & \multicolumn{1}{|c|}{ Quantity } & \multicolumn{1}{c}{ Percentage } \\
\hline Around 1 hour & 22 & $6.88 \%$ \\
\hline From 1-5 hours & 119 & $37.19 \%$ \\
\hline From 5-10 hours & 112 & $35.00 \%$ \\
\hline From 10-24 hours & 67 & $20.94 \%$ \\
\hline
\end{tabular}

According to the results of my questionnaire, 55.94\% of Moscow University students use a mobile phone every day for five hours or more. A very similar length of time is confirmed by the results of other studies conducted by eMarketer among Americans aged 18+ (2018) and 
Flurry Analytic for 2013-2016 (2016).

4.1.3 Analysis of the Level of Dependence on Mobile Phones for Students at Moscow Universities

According to the table below, 5.63\% of respondents believe that they are not at all dependent on mobile phones, $19.38 \%$ of respondents believe that most of the time they do not depend on mobile phones, $23.13 \%$ of respondents believe that they often depend on of mobile phones, while $10.31 \%$ of Moscow university students believe that they are very dependent on mobile phones and $41.56 \%$ - consider themselves to be partially dependent on mobile phones.

Table 2. Level of dependence on mobile phones

\begin{tabular}{l|l|l}
\hline & \multicolumn{1}{|c|}{ Quantity } & \multicolumn{1}{c}{ Percentage } \\
\hline Not at all dependent & 18 & $5.63 \%$ \\
\hline $\begin{array}{l}\text { Most of the time not } \\
\text { dependent }\end{array}$ & 62 & $19.38 \%$ \\
\hline Partially dependent & 133 & $41.56 \%$ \\
\hline Often dependent & 74 & $23.13 \%$ \\
\hline Very dependent & 33 & $10.31 \%$ \\
\hline
\end{tabular}

Here are a few excerpts from the more detailed responses of the respondents.

Often the dependent audience explained their reasons for being so. "My mobile phone is both my mirror and my umbrella, and my game console and much, much more. In a word, a mobile phone is a multi-tool, how can you not depend on it?" Another respondent wrote, "...since I'm studying at the mathematical faculty, I need a mobile phone not only for communication, but also for performing different kinds of assignments, as well as for doing homework and writing research papers, at times when it is inconvenient to use a laptop".

A very mobile audience-dependent audience explained his dependence with this answer: "The mobile phone has become the most important attribute of my everyday life: social networks, music, books, calls, and so on, that is, I really admit that at the moment, being without a mobile phone is like being without hands". Another of the very-dependent wrote, "...my reality is that today I can't go out without a phone, even for quick outings to the store near my house".

\subsection{Analysis of Primary Reasons of the Use of Mobile Media by Students of Moscow Universities}

The classification of reasons in modern science is made according to a variety of grounds. The reasons are divided into external and internal, major and non-principal, objective and subjective, and others. In this study, an attempt will be made to examine the reasons for using mobile media among students at Moscow universities in the following key aspects: internal, external causes and reasons of particular nature.

4.2.1 Internal Reasons for the Use of Mobile Media by Students of Moscow Universities

Speaking about the internal reasons for the use of mobile media by students of Moscow 
universities, I consider it reasonable to recall the well-known American psychologist Abraham Harold Maslow and his human needs pyramid, which hierarchically represents all human needs: physiological, safety, love and belonging to something, respect and recognition, self-fulfillment.

Physiological needs and needs for security are not so acute in modern society today, the needs for love and belonging to something, respect and recognition, cognition and self-fulfillment have become up to date. And here the mobile media are starting to play a key moment in their implementation. Therefore, among the main internal reasons for using mobile media are the following:

(a) The need for human love and belonging to something

During the survey, following situation was presented to the respondents: when you are bored, lonely and have other related sensations, the phone helps to solve these problems. And according to the data in the table below, $22.81 \%$ of respondents absolutely agree and $24.37 \%$ agree with this statement, and also 12.18 of respondents disagree with this statement and $10.62 \%$ absolutely disagree.

Table 3. When you are bored, lonely and have other related sensations, the phone helps to solve these problems

\begin{tabular}{l|l|l}
\hline & \multicolumn{1}{|c|}{ Quantity } & \multicolumn{1}{c}{ Percentage } \\
\hline Absolutely Disagree & 34 & $10.62 \%$ \\
\hline Disagree & 39 & $12.18 \%$ \\
\hline Partially Agree & 96 & $30.00 \%$ \\
\hline Agree & 78 & $24.37 \%$ \\
\hline Absolutely Agree & 73 & $22.81 \%$ \\
\hline
\end{tabular}

That is, there is the highest rate $(47.18 \%)$ of students agree with the above proposed situation to one degree or another. The lowest rate $(22.80 \%)$ of students disagreeing with this statement in one degree or another.

(б) The need for respect and recognition

During the survey, following situation was presented to the respondents: Solve important and urgent matters, help and other similar actions. And according to the data in the table below, $19.68 \%$ of respondents absolutely agree and $21.87 \%$ agree with this statement, and also $13.43 \%$ of respondents disagree with this statement and $8.43 \%$ absolutely disagree.

Table 4. Solve important and urgent matters, help and other similar actions

\begin{tabular}{l|l|l}
\hline & \multicolumn{1}{|c|}{ Quantity } & \multicolumn{1}{c}{ Percentage } \\
\hline Absolutely Disagree & 27 & $8.43 \%$ \\
\hline Disagree & 43 & $13.43 \%$ \\
\hline Partially Agree & 117 & $36.56 \%$ \\
\hline Agree & 70 & $21.87 \%$ \\
\hline Absolutely Agree & 63 & $19.68 \%$ \\
\hline
\end{tabular}




\section{Macrothink}

International Journal of Human Resource Studies

ISSN 2162-3058

2019, Vol. 9, No. 2

That is, there is the highest rate $(41.55 \%)$ of students agree with the above proposed situation to one degree or another. The lowest rate $(21.86 \%)$ of students disagreeing with this statement in one degree or another.

(c) The need for the pursuit of cognition and self-fulfillment

During the survey, following situation was presented to the respondents: using mobile media to search for materials related to studies, self-development and other related moments. And according to the data in the table below, $45.32 \%$ of respondents absolutely agree and $34.06 \%$ agree with this statement, and also $1.87 \%$ of respondents disagree with this statement and $2.5 \%$ absolutely disagree.

Table 5. Using mobile media to search for materials related to studies, self-development and other related moments

\begin{tabular}{l|l|l}
\hline & \multicolumn{1}{|c|}{ Quantity } & \multicolumn{1}{c}{ Percentage } \\
\hline Absolutely Disagree & 8 & $2.5 \%$ \\
\hline Disagree & 6 & $1.87 \%$ \\
\hline Partially Agree & 42 & $13.12 \%$ \\
\hline Agree & 109 & $34.06 \%$ \\
\hline Absolutely Agree & 145 & $45.32 \%$ \\
\hline
\end{tabular}

That is, there is the highest rate $(79.00 \%)$ of students agree with the above proposed situation to one degree or another. The lowest rate $(4.30 \%)$ of students disagreeing with this statement in one degree or another.

\subsubsection{External Reasons for the Use of Mobile Media by Students of Moscow Universities}

Considering the external reasons for the use of mobile media by students of Moscow universities, we highlight the following:

Multitasking, multi-functionality and ease of use of mobile media.

During the survey, following situation was presented to the respondents: the reason for using mobile media lies in its multitasking, multi-functionality and ease of use. And according to the data in the table below, $58.75 \%$ of respondents absolutely agree and $25.00 \%$ agree with this statement, and also $4.68 \%$ of respondents disagree with this statement and $2.81 \%$ absolutely disagree.

Table 6. The reason for using mobile media lies in its multitasking, multi-functionality and ease of use

\begin{tabular}{l|l|l}
\hline & \multicolumn{1}{|c|}{ Quantity } & \multicolumn{1}{c}{ Percentage } \\
\hline Absolutely Disagree & 9 & $2.81 \%$ \\
\hline Disagree & 15 & $4.68 \%$ \\
\hline Partially Agree & 28 & $8.75 \%$ \\
\hline Agree & 80 & $25.00 \%$ \\
\hline Absolutely Agree & 188 & $58.75 \%$ \\
\hline
\end{tabular}




\section{Macrothink}

International Journal of Human Resource Studies

ISSN 2162-3058

2019, Vol. 9, No. 2

That is, there is the highest rate $(83.75 \%)$ of students agree with the above proposed situation to one degree or another. The lowest rate $(7.49 \%)$ of students disagreeing with this statement in one degree or another.

(a) Availability of acquisition and the ubiquity of the use of mobile media.

During the survey, following situation was presented to the respondents: the reason of using is vailability of acquisition and the ubiquity of the use of mobile media. And according to the data in the table below, $65.00 \%$ of respondents absolutely agree and $18.12 \%$ agree with this statement, and also $3.75 \%$ of respondents disagree with this statement and $2.5 \%$ absolutely disagree.

Table 7. The reason of using is vailability of acquisition and the ubiquity of the use of mobile media

\begin{tabular}{l|l|l}
\hline & \multicolumn{1}{|c|}{ Quantity } & \multicolumn{1}{c}{ Percentage } \\
\hline Absolutely Disagree & 8 & $2.5 \%$ \\
\hline Disagree & 12 & $3.75 \%$ \\
\hline Partially Agree & 34 & $10.62 \%$ \\
\hline Agree & 58 & $18.12 \%$ \\
\hline Absolutely Agree & 208 & $65.00 \%$ \\
\hline
\end{tabular}

That is, there is the highest rate $(83.12 \%)$ of students agree with the above proposed situation to one degree or another. The lowest rate $(6.25 \%)$ of students disagreeing with this statement in one degree or another.

(b) The use of mobile media by the sample "all the others use and I use"

During the survey, following situation was presented to the respondents: the reason of using mobile media is the use of mobile media by the sample "all the others use and I use". And according to the data in the table below, $24.37 \%$ of respondents absolutely agree and $24.06 \%$ agree with this statement, and also $21.25 \%$ of respondents disagree with this statement and $16.56 \%$ absolutely disagree.

Table 8 . The reason of using mobile media is the use of mobile media by the sample "all the others use and I use"

\begin{tabular}{l|l|l}
\hline & \multicolumn{1}{|c|}{ Quantity } & \multicolumn{1}{c}{ Percentage } \\
\hline Absolutely Disagree & 53 & $16.56 \%$ \\
\hline Disagree & 68 & $21.25 \%$ \\
\hline Partially Agree & 44 & $13.75 \%$ \\
\hline Agree & 77 & $24.06 \%$ \\
\hline Absolutely Agree & 78 & $24.37 \%$ \\
\hline
\end{tabular}

That is, there is the highest rate $(48.43 \%)$ of students agree with the above proposed situation to one degree or another. The lowest rate $(37.81 \%)$ of students disagreeing with this statement in one degree or another. 
4.2.3 The reasons for the Particular Nature of the Use of Mobile Media by Students of Moscow Universities

Considering the reasons for the use of mobile media by students of Moscow universities, the reason for the special nature was taken separately not by chance: the use of mobile media by the young generation is the situation of the era as a whole. The habits and traditions of using mobile media primarily affect two generations such as $\mathrm{Y}$ Generation (or Milleniums (Millennials) and Z Generation (or iGeneration).

Y Generation or Milleniums (Millennials) are users who were born since 1981 and met the new millennium at a fairly young age. Y Generation is primarily characterized by deep involvement in digital technology. Russian independent media consultant and teacher at the Faculty of Journalism of Moscow State University Alexander Amzin writes in his article [Amzin, 2016] that this segment of the audience is characterized by both good involvement in new technologies and its active development; access to the network and media consumption from several platforms at once; perception of new media as not inferior in authority to the traditional media.

Z Generation or iGeneration (Homeland Generation or New Silent Generation) are users who were born since 1995. They know how to work perfectly with any information, developing fast, can do several things at the same time, for example, write a message, listen to music, play a computer game and learn lessons. The peculiarities of the $\mathrm{Z}$ Generation are that they prefer to communicate with people without leaving their homes, and if past generations underline the importance of personal presence at meetings, then the $\mathrm{Z}$ Generation feels comfortable in online communication. The need for security is a priority. To keep abreast of new trends, to monitor high-tech innovations, and it is better to participate in the development yourself - this is the need that was "born" with them.

Z Generation is also called "digital humans". And this is really the first truly digital natives. The Digital natives term was coined by the American writter Marc Prensky. And he describes $\mathrm{Z}$ Generation as "people who are fundamentally different from everyone else: schoolchildren and students of the 2000s live surrounded with video games, music players, video cameras, mobile phones and the Web - and all of the above is an integral part of their lives, and their native language of this generation is digital language [2018].

Therefore, speaking of the reason for the particular nature, I want first of all to focus on the fact that the use of mobile media, mainly by $\mathrm{Z}$ Generation, or in our case, students of Moscow universities, is the use of mobile media, which does not imply the existence of any justified reasons for this, the use of mobile media by this generation is their just real norm of daily life. 
4.3 Satisfaction Degree Analysis of the Use of Mobile Media Among Students of Moscow Universities

4.3.1 Satisfaction Degree Analysis of the Use of Mobile Periodical Literature Among Students of Moscow Universities

The respondents were asked the following question: "Do the quality, streaming speed and the search system for visual and textual content of mobile periodical literature satisfy your needs?" According to the data in the table below, 33.53\% of those respondents who use mobile periodical literature (remind, that its more than half of all respondents) are very satisfied and $28.82 \%$ are satisfied with the use of mobile periodical literature. $11.18 \%$ are absolutely not satisfied and $7.06 \%$ are not satisfied with the use of mobile periodical literature. For the record, $19.41 \%$ of respondents who use mobile periodical literature are partially satisfied with mobile periodical literature.

Table 9. Do the quality, streaming speed and the search system for visual and textual content of mobile periodical literature satisfy your needs?

\begin{tabular}{l|l|l}
\hline & \multicolumn{1}{|c|}{ Quantity } & \multicolumn{1}{c}{ Percentage } \\
\hline Absolutely not satisfied & 19 & $11.18 \%$ \\
\hline Not satisfied & 12 & $7.06 \%$ \\
\hline Partially satisfied & 33 & $19.41 \%$ \\
\hline Satisfied & 49 & $28.82 \%$ \\
\hline Very satisfied & 57 & $33.53 \%$ \\
\hline
\end{tabular}

Here are a few excerpts from the more detailed responses of the respondents.

Those who consider mobile periodical literature unsatisfactory explained their opinion in the following words: "I, sometimes, question the choice of font, as I often read mobile newspapers on transportation and my eyes are constantly getting tired." There was also a comment that "I think that photo playback quality often fails." Another respondent notes that "Very often, news articles that interest me and spam, which cannot be turned off, appear together in mobile newspapers, and this greatly interferes with reading the newspaper and concentrating on the content of the material."

Those who consider mobile periodical literature absolutely unsatisfactory explained their opinion in the following words: "Sometimes a mobile newspaper is very poorly designed, and often articles open slowly and require a very large amount of RAM." Another respondent notes that "It seems to me that often when reading mobile newspapers one can see a real deception when submitting information, inaccuracies are sometimes visible, and so on."

4.3.2 Satisfaction Degree Analysis of the Use of Mobile TV Among Students of Moscow Universities

The respondents were asked the following question: "Do the quality, streaming speed and the search system for visual content of mobile TV satisfy your needs?" According to the data in the table below, $21.76 \%$ of those respondents who use mobile TV (remind, that its more than half of all respondents) are very satisfied and $22.35 \%$ are satisfied with the use of mobile TV. 
$18.82 \%$ are absolutely not satisfied and $8.24 \%$ are not satisfied with the use of mobile TV. For the record, $28.82 \%$ of respondents who use mobile TV are partially satisfied with mobile TV.

Table 10. Do the quality, streaming speed and search system for visual content of mobile TV satisfy your needs?

\begin{tabular}{l|l|l}
\hline & \multicolumn{1}{|c|}{ Quantity } & \multicolumn{1}{c}{ Percentage } \\
\hline Absolutely not satisfied & 32 & $18.82 \%$ \\
\hline Not satisfied & 14 & $8.24 \%$ \\
\hline Partially satisfied & 49 & $28.82 \%$ \\
\hline Satisfied & 38 & $22.35 \%$ \\
\hline Very satisfied & 37 & $21.76 \%$ \\
\hline
\end{tabular}

Here are a few excerpts from the more detailed responses of the respondents.

Those who consider mobile TV unsatisfactory explained their opinion in the following words: "I believe that mobile TV does not work well on the phone, so for now it's better to watch television at home on the couch like our parents do." Another student wrote that "I'm not comfortable watching mobile TV on the phone, maybe it's just a matter of habit, I don't know." There was also a comment that "Sometimes you want to watch mobile TV, but almost always the streaming speed is slow and all desire to watch mobile TV dissipates quickly."

Those who consider mobile TV absolutely unsatisfactory explained their opinion in the following words: "It seems to me that the speed is very, very slow, and the quality is also very bad, all this spoils the mood together with the very desire to watch mobile TV at all." There was also a comment that "Mobile TV in Russia is not yet optimized for mobile networks." Another student wrote that "In my experience of using mobile TV, the sound was often lagging behind the video and there was also this constant waiting for it to buffer - all this makes viewing of mobile television almost impossible for me."

4.3.3 Satisfaction Degree Analysis of the Use of Mobile Cinema Among Students of Moscow Universities

The respondents were asked the following question: "Do the image quality and playback speed of mobile cinema satisfy your needs?"

According to the data in the table below, $27.65 \%$ of those respondents who use mobile cinema (remind, that its more than half of all respondents) are very satisfied and $34.71 \%$ are satisfied with the use of mobile movie. $10.00 \%$ are absolutely not satisfied and $5.88 \%$ are not satisfied with the use of mobile movie. For the record, $21.76 \%$ of respondents who use mobile cinema are partially satisfied with mobile movie. 
Table 11. Does the image quality, playback speed of mobile cinema satisfy your needs?

\begin{tabular}{l|l|l}
\hline & \multicolumn{1}{|c}{ Quantity } & \multicolumn{1}{c}{ Percentage } \\
\hline Absolutely not satisfied & 17 & $10.00 \%$ \\
\hline Not satisfied & 10 & $5.88 \%$ \\
\hline Partially satisfied & 37 & $21.76 \%$ \\
\hline Satisfied & 59 & $34.71 \%$ \\
\hline Very satisfied & 47 & $27.65 \%$ \\
\hline
\end{tabular}

Here are a few excerpts from the more detailed responses of the respondents.

Those who consider mobile cinema unsatisfactory explained their opinion in the following words: "When watching a mobile movie it often stalls, thereby spoiling the whole atmosphere of the viewing and the mood in general." There was also a comment that "It may be that the quality of the film is good, but the speed of playback is constantly slow, or it often happens that the film just turns off and I can't do anything about it."

Those who consider mobile cinema absolutely unsatisfactory explained their opinion in the following words: "For the most part, movies load poorly on my phone." Another student wrote that "I am not very satisfied with both the fact that mobile cinema is illegal for viewing and the high cost of the legal version." There was also a comment that "Mobile cinema downloads on my phone very slowly."

4.3.4 Satisfaction Degree Analysis of the Use of Mobile Video Among Students of Moscow Universities

The respondents were asked the following question: "Do the image quality and playback speed of mobile video satisfy your needs?" According to the data in the table below, $46.47 \%$ of those respondents who use mobile video (remind, that its more than half of all respondents) are very satisfied and $32.94 \%$ are satisfied with the use of mobile video. $3.53 \%$ are absolutely not satisfied and $5.88 \%$ are not satisfied with the use of mobile video. For the record, $11.18 \%$ of respondents who use mobile video are partially satisfied with mobile video.

Table 12. Does the image quality, speed of transmission and reception of the mobile video satisfy your needs?

\begin{tabular}{l|l|l}
\hline & \multicolumn{1}{|c|}{ Quantity } & \multicolumn{2}{c}{ Percentage } \\
\hline Absolutely not satisfied & 6 & $3.53 \%$ \\
\hline Not satisfied & 10 & $5.88 \%$ \\
\hline Partially satisfied & 19 & $11.18 \%$ \\
\hline Satisfied & 56 & $32.94 \%$ \\
\hline Very satisfied & 79 & $46.47 \%$ \\
\hline
\end{tabular}

Here are a few excerpts from the more detailed responses of the respondents.

Those who consider mobile video unsatisfactory explained their opinion in the following words: "I'm having troubles playing it." Another student wrote that "I do not always have a good reception, and the mobile video loads for a long time." 


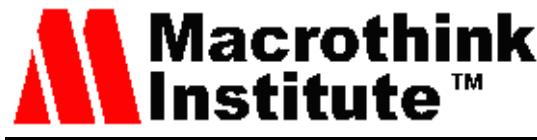

Those who consider mobile video absolutely unsatisfactory explained their opinion in the following words: "Mobile video is always of a very bad quality, sometimes not only the Internet is slow, but everything spontaneously disappears in general." Another student wrote that "When using mobile video on my phone, the quality of the video is very poor."

4.3.5 Satisfaction Degree Analysis of the Use of Mobile Internet Among Students of Moscow Universities

The respondents were asked the following question: "Do the range of online services and the range of plans for mobile Internet satisfy your needs?"

According to the data in the table below, $37.65 \%$ of those respondents who use mobile Internet (remind, that its more than half of all respondents) are very satisfied and $31.18 \%$ are satisfied with the use of mobile Internet. 5.29\% are absolutely not satisfied and $8.24 \%$ are not satisfied with the use of mobile Internet. For the record, $17.65 \%$ of respondents who use mobile Internet are partially satisfied with mobile Internet.

Table 13. Does the range of online services and the range of plans for mobile Internet satisfy your needs?

\begin{tabular}{l|l|l}
\hline & \multicolumn{1}{|c|}{ Quantity } & \multicolumn{1}{c}{ Percentage } \\
\hline Absolutely not satisfied & 9 & $5.29 \%$ \\
\hline Not satisfied & 14 & $8.24 \%$ \\
\hline Partially satisfied & 30 & $17.65 \%$ \\
\hline Satisfied & 53 & $31.18 \%$ \\
\hline Very satisfied & 64 & $37.65 \%$ \\
\hline
\end{tabular}

Here are a few excerpts from the more detailed responses of the respondents.

Those who consider mobile Internet unsatisfactory explained their opinion in the following words: "It often happens that the Internet is slow, and I often run out of data very quickly." Another respondent notes that "I don't like the price / quality ratio, and I would also like more variability." Another student wrote that "My mobile Internet plan is not very good, so there I don't feel satisfaction in using it."

Those who consider mobile Internet absolutely unsatisfactory explained their opinion in the following words: "It seems to me that mobile Internet is very expensive, and the operator always uses money for something else." There was also a comment that "My operator does not provide a convenient plan." Another student wrote that "It seems to me that the Internet is very expensive and there is often no signal in the subway."

4.3.6 Satisfaction Degree Analysis of the Use of GPRS Traffic Among Students of Moscow Universities

The respondents were asked the following question: "Does GPRS traffic satisfy your needs?" According to the data in the table below, $41.29 \%$ of all respondents are very satisfied and $24.19 \%$ are satisfied with the use of GPRS. $7.10 \%$ of all respondents are absolutely not satisfied and $7.42 \%$ are not satisfied with the use of GPRS. For the record, $20.00 \%$ of 
respondents are partially satisfied with GPRS.

Table 14. Does GPRS traffic satisfy your needs

\begin{tabular}{l|l|l}
\hline & \multicolumn{1}{|c|}{ Quantity } & \multicolumn{1}{c}{ Percentage } \\
\hline Absolutely not satisfied & 22 & $7.10 \%$ \\
\hline Not satisfied & 23 & $7.42 \%$ \\
\hline Partially satisfied & 62 & $20.00 \%$ \\
\hline Satisfied & 75 & $24.19 \%$ \\
\hline Very satisfied & 128 & $41.29 \%$ \\
\hline
\end{tabular}

Here are a few excerpts from the more detailed responses of the respondents.

Those who consider GPRS traffic unsatisfactory explained their opinion in the following words: "I have enough GPRS traffic only for online reading, but I've always lacked traffic for music and video." There was also a comment that "I have little use of GPRS traffic, but I pay a lot for it."

Those who consider GPRS traffic absolutely unsatisfactory explained their opinion in the following words: "GPRS traffic is very expensive." Another student wrote that "My GPRS traffic is very limited and it is never enough, even for good money." Another respondent notes that "I am not satisfied with the traffic, since the cost of it in the absence of unlimited traffic is large, so I try to use it as little as possible, which is sometimes inconvenient in daily life."

\section{Conclusion}

Firstly, the aim of this study is to highlight the student demographic within the overall audience of mobile media. Students represent a unique population known for its mobility and distinctive lifestyle collectively belonging to institutions of higher learning. Students constitute the bulk of the world's intellectual and managerial potential, and have the greatest prospects for developing into the elite of society in general. Having considered the main reasons why university students in Moscow use mobile media gives us a deeper understanding of the overall picture researching the topic of mobile media.

Secondly, mobile media, as a new communication tool, was considered within the concept of use and satisfaction. It should be emphasized that in all five key situations (mobile periodical literature, mobile TV, mobile cinema, mobile video, mobile internet), the most respondents believe that they are more or less satisfied in using mobile media. In general, students choose a particular source of media information in order to satisfy diverse personal needs; and accordingly, the choice of a particular source depends on the expected satisfaction.

Thirdly, as students constitute the core potential of any society, to whom it is necessary to show special attention and care, it is advisable to raise awareness to trends in extreme tendencies among university students and their use of mobile media - case in point, $55.94 \%$ of Moscow University students use their mobile phones for five or more hours per day. Assuming that the mobile phone has a thermal impact on a person (possibly bringing harm to various human organs) and non-thermal effects (possibly influencing electrical processes in 
the brain), it follows logically that mobile phone use requires a further research to inform increased regulations determining appropriate time intervals for its use.

A careful study of the instruction manual for the most popular mobile phone among Moscow University students - the iPhone, revealed no specific information regarding the recommendations for the recommended time frame for using the smartphone. Russian scientists suggest in [2006] that the maximum use of a mobile phone for an adult person should be no more than 30 minutes a day, let alone 5 hours or more, as is now common among young adults today. This finding highlights the need for further study of mobile media and its effect on young people today.

Fourthly, the investigation into the role, origin and use of mobile media, it's evolution and efficiency, grows daily. Therefore, hopefully, our study will not only become an integral part of the author's PhD thesis, but will also be able to provide factual assistance for the future analysts of mobile media in the development of their work, whether they are mobile media designers, or the researchers of mobile media themselves.

\section{References}

EMarketer.com. (2018). Average Time Spent per Day with Mobile Internet with among Us Mobile Users In App vs. Mobile Web, 2012-2018.

Flurry Analytics, comScore, Facebook, NetMarketShare. (2016). USDailyMobileTimeSpend

Gerard, G., \& Larissa, H. (2017). The Routledge Companion to Mobile Media. New York.

Katz, E., Gurevitch, M., \& Haas, H. (1973). On the use of mass media for important things. American Sociological Review, 38, 164. https://doi.org/10.2307/2094393

LaRose, R., Mastro, D., \& Eastin, M. S. (2001). Understanding Internet usage a social-cognitive approach to uses and gratifications. Social Science Computer Review, 19(4). 395. https://doi.org/10.1177/089443930101900401

McQuail, D., Blumer, J. G., \& Brown, J. R. (1972). The television audience. A revised perspective. Sociology of mass communications.135.

Pavlou, P. A., Liang, H., \& Xue, Y. (2006). Understanding and mitigating uncertainty in online environments: a principal-agent perspective. MIS quarterly, 31(1), 112. https://doi.org/10.1177/089443930101900401

Wikipedia. (2018). https://ru.wikipedia.org/wiki/Digital_Native

Амзин А. и др. (2016). Как новые медиа изменили журналистику (How New Media Has Changed Journalism). 2012-2016 / А. Амзин, А. Галустян, В. Гатов, М. Кастельс, Д. Кульчицкая, Н. Лосева, М. Паркс, С. Паранько, О. Силантьева, Б. ван дер Хаак; под научной редакцией С. Балмаевой и М. Лукиной (pp. 86-140) Екатеренбург: Гуманитарный университет.

Под научной редакцией С. Балмаевой и М. Лукиной. (2016). Как новые медиа изменили журналистику (How New Media Has Changed Journalism). Екатеренбург: Гуманитарный 
университет.

Управление федеральной службы по надзору в сфере защиты прав потребителей и благополучия. (2006).The Federal Service for Supervision of Consumer Rights Protection and Welfare.

匡文波. (2012). 手机媒体概论(Introduction to Mobile Media). 北京: 中国人民大学出版社. 吕菁. (2015). 贵州大学生手机媒体的使用行为调查与分析 (Investigation and Analysis of the Use of Mobile Media in Guizhou College Students). China Academical Journal Electronic Publishing House.

马烨. (2011). 大学生对于手机媒体的使用与满足分析一一基于对北京市24名大学生的 深度访谈 (The analysis on the college student use and gratifications of the mobile media) 北京: China Youth University for political sciences.

严三九. (2011). 新媒体概论 (Introduction to New Media). 北京: 化学工业出版.

朱海松. (2008). 手机媒体 (Mobile Media). 广州: 广东经济出版社.

\section{Copyright Disclaimer}

Copyright for this article is retained by the author(s), with first publication rights granted to the journal.

This is an open-access article distributed under the terms and conditions of the Creative Commons Attribution license (http://creativecommons.org/licenses/by/4.0/). 